\title{
Biodiversity and conservation of insects and other invertebrates
}

\author{
David L. Hawksworth
}

Published online: 4 November 2011

(C) Springer Science+Business Media B.V. 2011

\begin{abstract}
The thematic issue of Biodiversity and Conservation devoted to the biodiversity and conservation of insects and other invertebrates is introduced. The issue comprises 23 original research papers covering diverse habitats from forests to grasslands, ponds and rivers to coasts, and the tropics to boreal regions. Amongst the organisms discussed are ants, bees, beetles, butterflies, crabs, microgastropods, millipedes, spiders, and weevils. Some of the difficulties of conserving the most species-rich groups of eukaryotes, in the face of ignorance as to their identities and positions in ecological processes, are noted and the precautionary principle is seen as a pragmatic and responsible approach.
\end{abstract}

Keywords Arthropods · Biodiversity - Bioindicators · Conservation · Ecology · Environment $\cdot$ Methodology $\cdot$ Monitoring

The insects, and other speciose groups of invertebrates, pose particular challenges for understanding and conserving biodiversity. Not only do they constitute the vast proportion of all eukaryotes so far recognized, huge numbers of insect species (perhaps $85 \%$ or more) have yet to be formally named. This situation is only marginally better than that in the even more poorly known fungi. As a result of generations of collecting and documenting by both naturalists and professional entomologists, the inventories of some insect groups, such as butterflies and orthopterans, are much more complete; these are, however, the exception.

Yet the extent to which such taxa can serve as surrogates for other insects in conservation action plans, has to be questioned because of the disparate ecological niches occupied. A major challenge for conservationists is the protection of little-known, or unknown organisms, responsible for key ecological processes that are critical to the maintenance of Earth's ecosystems. These range from agricultural lands to tropical forests

D. L. Hawksworth $(\bowtie)$

Departamento de Biología Vegetal II, Facultad de Farmacia, Universidad Complutense de Madrid, Plaza Ramón y Cajal, Ciudad Universitaria, 28040 Madrid, Spain

e-mail: d.hawksworth@nhm.ac.uk

D. L. Hawksworth

Department of Botany, Natural History Museum, Cromwell Road, London SW7 5BD, UK 
and the tundra-yet the preservation of those organisms, and the ecological process in which they are involved, is critical for the continuance of Life as we know it into future eons.

Since its inception in 1992, one of the aims of Biodiversity and Conservation has been to raise awareness, within the wider conservation community, of issues related to less-studied groups of organisms. To that end, this thematic issue of Biodiversity and Conservation brings together a selection of 23 studies, submitted to the journal, which address diverse aspects of the biodiversity and conservation of insects and some other invertebrates. As these articles have been selected from regular submissions to the journal, and are not invited contributions, the coverage is necessarily eclectic rather than comprehensive, and the papers report original work rather than present reviews. However, in selecting papers for consideration for publication in the journal, one criterion used by the Editors is their potential interest to a broad range of biodiversity scientists and conservationists. Thus, it is anticipated that this selection of contributions will be attractive not just to entomologists and invertebrate zoologists.

A key issue in woodland and forest management policy is whether dead wood should be left in situ or removed. The consensus is now for its retention because of the so called "saproxylics". These are specialized fungi and insects confined to dead wood which, particularly in old-growth forest, include critically endangered or vulnerable species. These are the topic of four papers included here (Ranius and Roberge 2011; Svensson et al. 2011; Ranius et al. 2011; Hébert et al. 2011). While it is beetles are the principle insect saproxylics of concern in forest ecosystems, invasive beetles can be significant factors in forest health (Borkowski and Podlaski 2011), and they are far from the only insects and other invertebrates to be considered. Examples of others groups included here are spiders (Hsieh and Linsenmair 2011), millipedes (Galanes and Thomlinson 2011), bees (Abrahamczyk et al. 2011), and a leaf-mining weevil (Kenis and co-workers 2011).

Outside forested areas, these kinds of organisms are also important in biodiversity management and conservation. For instance, ants have been found to have a role as bioindicators of land-management types (Chen et al. 2011); ground beetle assemblages may reflect soil perturbations (Ödman et al. 2011); and dung beetle assemblages can also be linked to human influences (Carpaneto et al. 2011). Other papers discuss invertebrate and vertebrate diversity in pampas vegetation (Medan et al. 2011); the conservation of the always fascinating trapdoor spiders (Engelbrecht and Prendini 2011); and parasitism in a bog-inhabiting butterfly (Schtickzelle and co-workers 2011).

Invertebrates have a long history of use as bioindicators of water quality, but may also be responsive to, or be threatened by, climatic change. This is particularly so in specialized habitats such as isolated water "traps" on mountains (Sauer et al. 2011). Included here is also an instance of the effects of stream restoration on carabid beetles and vegetation (Januschke et al. 2011); the use of invertebrates as a criterion in river assessments in Australia (Stewart 2011); and how invertebrate diversity correlates with that on pond plants (Hassall et al. 2011). The journal does not receive as many papers on coastal and marine organisms as I would like to see, but two involving invertebrates and coastal habitats are included here: one concerns the diversity of microgastropods in a tropical coastal environment (Albano et al. 2011) and the other, crabs in Brazilian mangrove communities (Colpo et al. 2011).

Other key aspects of biodiversity and conservation include the roles of insects as pollinators, and an example involving Agave is included (Lindsay et al. 2011). There is also the issue of introduced and invasive pests and their control, and a case involving an ant species in Australia is presented (Hoffmann 2011). The location and introduction of 
parasitoids of crop pests into new regions as a part of controlled biocontrol programmes is a further aspect of importance.

In such numerous groups of organisms, there is almost no end to the types of interorganismal interactions that could be described which would add to their importance for conservation. Species never live in isolation. For instance, in conserving a beetle species, any fungi obligately occurring on its exoskeleton, or living inside its hind-gut, could also be safeguarded (Weir and Hammond 1997, Lichtwardt 2012). For numerous other cases, texts on the biodiversity and ecology of insects and other invertebrates should be consulted, and four pertinent works focusing on insects are discussed at the end of this thematic issue (Hawksworth 2011).

In the conservation of insects, and other speciose groups, where a high proportion of the species are unnamed and their ecological niches are unknown, the main focus has to be the protection of sites that are, as yet, hardly affected by human activity. Those are the places that will be the reservoirs (the "in situ genetic resource collections") that harbour the pollinators of plants, potential biocontrol agents of plants and insect pests, re-cyclers of dead animals and plants, and constitute the food or habitat of other organisms. The "precautionary principle" (Cooney and Dickson 2005) is consequently emphasized by Samways (2005) with respect to insect conservation policy. That is, to safeguard or mitigate as far as possible any potential losses. As we know so little of the possible consequences of the loss of any single species, the precautionary approach is possibly the only pragmatic and responsible one when considering the conservation of biodiversity in such groups.

There are, consequently, enormous opportunities for original research in documenting the insects and other invertebrates in particular habitats, as well as in unraveling their often-fascinating and unexpected roles and interactions in ecological networks and food webs. I hope that this collection of papers, which provides a snap-shot of current research in this particular aspect of biodiversity and conservation, will help inspire more enquiry. They may also have a role in educational courses as a series of case-studies. This will expose both graduate students and conservation scientists to approaches currently being taken to investigate and conserve these much-neglected, but so important, elements in the diversity of Life.

\section{References}

Abrahamczyk S, Gottleuber P, Matauschek C, Kessler M (2011) Diversity and community composition of euglossine bee assemblages (Hymenoptera: Apidae) in western Amazonia. Biodiv Conserv 20. doi:10.1007/s10531-011-0105-1

Albano PG, Sabelli B, Bouchet P (2011) The challenge of small and rare species in marine biodiversity surveys: microgastropod diversity in a complex tropical coastal environment. Biodiv Conserv 20. doi:10.1007/s10531-011-0117-x

Benjamin D. Hoffmann (2011) Eradication of populations of an invasive ant in northern Australia: successes, failures and lessons for management. Biodiv Conserv 20. doi:10.1007/s10531-011-0106-0

Borkowski A, Podlaski R (2011) Statistical evaluation of Ips typographus population density: a useful tool in protected areas and conservation-oriented forestry. Biodiv Conserv 20. doi:10.1007/s10531-0110121-1

Carpaneto GM, Mazziotta A, Pittino R, Luiselli L (2011) Exploring co-extinction correlates: the effects of habitat, biogeography and anthropogenic factors on ground squirrels-dung beetles associations. Biodiv Conserv 20. doi:10.1007/s10531-011-0162-5

Chen Y-Q, Li Q, Chen Y-L, Lu Z-X, Zhou X-Y (2011) Ant diversity and bio-indicators in land management of lac insect agroecosystem in Southwestern China. Biodiv Conserv 20. doi:10.1007/s10531-0110097-x 
Choutt J, Turlure C, Baguette M, Schtickzelle N (2011) Parasitism cost of living in a high quality habitat in the bog fritillary butterfly. Biodiv Conserv 20. doi:10.1007/s10531-011-0151-8

Colpo KD, Chacur MM, Guimarães FJ, Negreiros-Fransozo ML (2011) Subtropical Brazilian mangroves as a refuge of crab (Decapoda: Brachyura) diversity. doi:10.1007/s10531-011-0125-x

Cooney R, Dickinson B (2005) Biodiversity \& the Precautionary principle: risk and uncertainty in conservation and sustainable use. Earthscan, London

Lindsay DL, Bailey P, Lance RF, Clifford MJ, Delph R, et al (2011) Effects of a nonnative, invasive lovegrass on Agave palmeri distribution, abundance, and insect pollinator communities. Biodiv Conserv 20. doi:10.1007/s10531-011-0133-X

Engelbrecht I, Prendini L (2011) Assessing the taxonomic resolution of southern African trapdoor spiders (Araneae: Ctenizidae; Cyrtaucheniidae; Idiopidae) and implications for their conservation. Biodiv Conserv 20. doi:10.1007/s10531-011-0115-z

Hassall C, Hollinshead J, Hull A (2011) Environmental correlates of plant and invertebrate species richness in ponds. Biodiv Conserv 20. doi:10.1007/s10531-011-0142-9

Hsieh Y-L, Linsenmair KE (2011) Underestimated spider diversity in a temperate beech forest. Biodiv Conserv 20. doi:10.1007/s10531-011-0158-1

Hawkswoth DL (2011) Books on insect biodiversity and conservation. Biodiv Conserv 20. doi:10.1007/ s10531-011-0177-y

Hébert C, Janssen P, Fortin D (2011) Biodiversity conservation in old-growth boreal forest: black spruce and balsam fir snags harbour distinct assemblages of saproxylic beetles. Biodiv Conserv 20. doi: 10.1007/s10531-011-0127-8

Ileana T. Galanes, John R. Thomlinson (2011) Soil millipede diversity in tropical forest patches and its relation to landscape structure in northeastern Puerto Rico. Biodiv Conserv 20. doi:10.1007/s10531011-0128-7

Januschke K, Brunzel S, Haase P, Hering D (2011) Effects of stream restorations on riparian mesohabitats, vegetation and carabid beetles. Biodiv Conserv 20. doi:10.1007/s10531-011-0119-8

Lichtwardt RW (2012) Trichomycete gut fungi from tropical regions of the world. Biodiv Conserv 21: in press, Biodiv Conserv 20. doi:10.1007/s10531-011-0146-5

Medan D, Torretta JP, Hodara K, de la Fuente EB, Montaldo NH (2011) Effects of agriculture expansion and intensification on the vertebrate and invertebrate diversity in the Pampas of Argentina. Biodiv Conserv 20. doi:10.1007/s10531-011-0118-9

Ödman AM, Mårtensson L-M, Sjöholm C, Olsson PA (2011) Immediate responses in soil chemistry, vegetation and ground beetles to soil perturbation when implemented as a restoration measure in decalcified sandy grassland. Biodiv Conserv 20. doi:10.1007/s10531-011-0108-y

Péré C, Bell R, Turlings TCJ, Kenis M (2011) Does the invasive horse-chestnut leaf mining moth, Cameraria ohridella, affect the native beech leaf mining weevil, Orchestes fagi, through apparent competition? Biodiv Conserv 20. doi:10.1007/s10531-011-0134-9

Ranius T, Roberge JM (2011) Effects of intensified forestry on the landscape-scale extinction risk of dead wood dependent species. Biodiv Conserv 20. doi:10.1007/s10531-011-0143-8

Ranius T, Martikainen P, Kouki J (2011) Colonisation of ephemeral forest habitats by specialised species: beetles and bugs associated with recently dead aspen wood. Biodiv Conserv 20. doi:10.1007/ s10531-011-0124-y

Samways MJ (2005) Insect diversity conservation. Cambridge University Press, Cambridge

Sauer J, Domisch S, Nowak C, Haase P (2011) Low mountain ranges: summit traps for montane freshwater species under climate change. Biodiv Conserv 20. doi:10.1007/s10531-011-0140-y

Stewart BA (2011) Assessing the ecological values of rivers: an application of a multi-criteria approach to rivers of the South Coast Region, Western Australia. Biodiv Conserv 20. doi:10.1007/s10531-0110111-3

Svensson GP, Sahlin U, Brage B, Larsson MC (2011) Should i stay or should i go? Modelling dispersal strategies in saproxylic insects based on pheromone capture and radio telemetry: a case study on the threatened hermit beetle Osmoderma eremita. Biodiv Conserv 20. doi:10.1007/s10531-011-0150-9

Weir A, Hammond PM (1997) Laboulbeniales on beetles: host utilization patterns and species richness of the parasites. Biodiv Conserv 6:701-719 